\title{
A new history of knowledge
}

In the summer of 1971, an 11-year-old boy in Gothenburg named Mats Lidström wrote a letter to Hans Palmstierna. Mats had recently read a report on the environment in the youth magazine Kamratposten in which Palmstierna had participated. The report had shocked Mats. 'Is our little Tellus really in such a bad way?' he asked, adding that it was terrible that there were people who destroyed the environment just to make money. 'They should be given a real lesson' for everything they did to 'people newly born'. Now it was his generation that would be forced 'to fight against humanity's possible downfall [and for its] existence'.

To find out more about the environmental problems, Mats had bought a copy of Plundring, svält, förgiftning. He thought it was extremely interesting and rich in content, but also depressing. 'How can anyone be happy in this society?' he wondered. He had taken the book to school several times so that he could read a chapter out loud. Not many of his classmates had wanted to listen. 'And that is an example of why the Earth is the way it is today', he said. Personally, he was thinking of some day becoming 'one of those people who work with the environment'. ${ }^{1}$

Palmstierna answered Mats promptly, kindly, and at length. $\mathrm{He}$ agreed that money and greed all too often governed the course of events. 'Like you, I am convinced that you and others born in the 1950s and 1960s will probably have to pay dearly for the mistakes that my generation and the generations immediately before me have made.' Continued environmental destruction must be prevented. Humanity had to be protected from itself. 'In the long run, it will be a question of surviving or not, if we do not mend our ways.'

1 Letter from Mats Lidström to Hans Palmstierna, 17 June 1971, 452/3/6 (HP ARBARK). 
Yet it was still possible to be happy. Many forces in society were working to change the situation. And one thing was for sure, Palmstierna stressed: 'more and more people are already listening and even more will listen in future, even though your friends are not doing so right now'. In time they would change. Besides, Palmstierna told Mats that new laws were about to be enacted. Very soon it would be 'a lot harder to sell environmentally hazardous products'. There was reason to be hopeful at the international level too. Next year, the UN would arrange a big environmental conference in Stockholm. Sometimes, of course, one might feel that everything was happening too slowly and progress was too slight. But there was no reason to be discouraged. 'What you and I can do, together with many others, is to try to make the necessary changes happen sooner, so it won't be too late.'

This exchange between Mats Lidström and Hans Palmstierna affords an insight into how knowledge of an environmental crisis was circulating in Swedish society in the early 1970s. It underlines the fact that knowledge was not just a matter for scientists, politicians, journalists, and environmental activists. Such knowledge could also make an 11-year-old schoolboy start to wonder. What would the world be like when he grew up? What challenges awaited him and his classmates? Was the environmental crisis really a threat to human survival?

Five years earlier, a primary schooler's worries about the future would hardly have been formulated in this way. In the mid-1960s, only a few people had talked about humanity standing on the brink of a global environmental crisis. But in the space of a few years in the late 1960s, a profound change occurred: a social breakthrough of knowledge. In this book I have mapped out and analysed how this change happened in Swedish society. It is now time for me to adopt an overall perspective. What are the most important results of this study? What does this investigation teach us about the breakthrough of environmental issues in Sweden? What new insights does this study offer to international environmental history research?

A final chapter, however, is not only a place to summarize and distil research results. It also provides an opportunity to consider the scholarly choices that were made and what their consequences were. Such consideration raises broader issues of a theoretical and methodological nature related to the study of history. What I

2 Letter from Hans Palmstierna to Mats Lidström, 19 June 1971, 452/3/6 (HP ARBARK). 
particularly want to consider here is the history-of-knowledge approach. How does my study contribute to defining and developing the history of knowledge as a research field? What more general insights and perspectives can historians of knowledge draw from it?

Finally, I would also like to take this opportunity to look beyond the present study. Does the historical narrative I have written have any significance for us today? Does the breakthrough of environmental issues in the years around 1970 make any difference to the global challenges facing humanity in the 2020s? Can we learn anything from it? My answers to these questions will of necessity be tentative and exploratory. I am a historian, not an interpreter of modern society or a political visionary. Nevertheless, I have thought about these issues for a long time, and I have some ideas that I would like to try to put into writing. My hope is that these thoughts, inspired by the study of history, will stimulate further discussion and form a platform which provides some sort of foothold. First of all, though, I will review what I believe to be the most important results of the study.

\section{The breakthrough of environmental issues in Sweden, 1967-1972}

The first point I would like to make concerns chronology. I believe this study has established that the big breakthrough of environmental issues in a Swedish context occurred in the autumn of 1967. It was then that the environmental debate greatly intensified and its content fundamentally changed. Of course, it is possible to draw the historical lines farther back. For the history of ideas and science, the late 1940s were the turning point. But from a history-ofknowledge perspective, the autumn of 1967 is more crucial. It was not until then that knowledge of an environmental crisis seriously began to circulate in Swedish society in general. From an international perspective, this is remarkably early. Moreover, by extension via the Stockholm Conference of 1972, the Swedish breakthrough had global consequences.

My second point deals with the actors who were the driving forces behind this breakthrough. Here I would like to single out the Swedish scientists who went public to warn of a looming global catastrophe. Hans Palmstierna, Karl-Erik Fichtelius, Svante Odén, Georg Borgström and others formed a chorus of warning voices. Together they made the national environmental debate gain momentum and change direction. The Swedish researchers were part of a 
larger international trend of scientists becoming more openly politically committed. However, what is striking when comparing Sweden with countries of the same size is how numerous, and how relatively synchronized, the Swedish researchers were. In the neighbouring Nordic countries - which resembled Sweden in many other ways nothing similar happened during this period. ${ }^{3}$

My third point has to do with the ways in which the social understanding of environmental problems changed during this breakthrough phase. It was characteristic of this period that environmental destruction began to be regarded as a matter of survival. Environmental issues thereby became linked to the two global perceptions of threat that were already circulating in society: the nuclear threat and overpopulation. These connections came to colour the rhetoric, the depictions, and the understanding of the environmental crisis in the years around 1970. From acid rain, mercury fish, and leaded petrol, connecting lines stretched out to the global level. For people like Rolf Edberg, Hans Palmstierna, Erik Isakson, and Wolter Arnberg, everything was connected. The environmental problems constituted a crisis for civilization at large.

My fourth point, however, indicates a different direction. This study has shown that the Swedish environmental debate contained other themes than the global and the apocalyptic dimensions. For actors such as Barbro Soller, Birgitta Odén, Stig Tejning, and Valfrid Paulsson, the national level had higher priority than the global one; and at the national level, the environmental debate was more low-key and focused on practicalities. It featured a profound belief that Swedish society could fix the environmental problems through a process of political decisions, ambitious research efforts, and expanded international cooperation. I would also like to emphasize that actors were able to move between, or encompass both, the two major themes of the environmental debate. The most striking example of this mobility is Hans Palmstierna.

The fifth point I would like to raise concerns the politicization of environmental issues and what this process did to the relevant knowledge. I would argue that the breakthrough phase in Sweden was characterized by relative consensus about the seriousness of the environmental problems and what needed to be done. In particular,

3 Jamison, Eyerman, and Cramer, The Making of the New Environmental Consciousness; Anker, 'Den store økologiske vekkelsen'; Räsänen, 'Converging Environmental Knowledge'; Larsson Heidenblad, 'En nordisk blick'; Notaker, 'Staging Discord'. 
there was widespread agreement on the need for information and its dissemination. The key task was to raise the level of knowledge of the general public and among politicians. From 1969 onwards, however, the lines of conflict became more apparent. Politicians, trade unions, industry, and new social movements sought to lead the environmental debate in different directions. Many groups wanted to make the issues their own. One consequence of this was that the political colour of environmental issues in Sweden in the years around 1970 was unclear, or, perhaps more accurately, variable. This meant that conflicting claims to possessing knowledge were made in the public sphere, even by scientific researchers such as Gösta Ehrensvärd and Tor Ragnar Gerholm. At the time of the Stockholm Conference in June 1972, it was far from obvious what was circulating as knowledge and what was regarded as ideological position statements.

This leads on to my sixth point, which concerns the issue of power over the social circulation of knowledge. If many voices were now being raised and the substance of knowledge was becoming more and more disputed, what was it that enabled some actors to have an impact while others did not? Which knowledge arenas and social forces were most important to the circulation of knowledge? Here I would like to single out Dagens Nyheter as a driving factor in the Swedish environmental debate. This study has repeatedly shown how the newspaper functioned as a link between the world of research and the general public. I would also like to stress the decisive - albeit manifold - role of Swedish Social Democracy in the historical process. This role includes such things as the establishment of the government enquiry into natural resources in 1964; the establishment of the National Environment Protection Board in 1967; Folksam's 'front-against-environmental-destruction' campaign in 1968 and 1969; and ABF's study groups based on Plundring, svält, förgiftning. In light of this, we can also find an explanation for Hans Palmstierna's having become so influential during the late 1960s. He had access to political, media, and organizational resources that no other contemporaneous environmental debater came close to. His access is remarkable from an international perspective as well. In comparison with Palmstierna, even the most influential actors, such as Rachel Carson and Barry Commoner, were very far from actual centres of political power.

My seventh and final point concerns the emergence of the environmental movements. This grassroots involvement holds a prominent position in both the historiography and the general historical 
consciousness. According to this view, it was via the alternative movements that environmental awareness emerged. In a country such as Denmark, one can with some justification say that this was the case; but not in Sweden. My study reveals that the big breakthrough of environmental issues in this country occurred several years before there were any environmental movements to speak of. It was the established social forces - the world of research, the political parties, the military, the major book publishers, and the daily newspapers - that were first out of the gate. From 1969 onwards, however, new social movements and the political rituals of the New Left became increasingly important to the circulation of knowledge pertaining to the environment. In the early 1970s, Nature and Youth Sweden and Björn Gillberg's environmental groups attracted a great deal of attention with their spectacular direct actions. Like Hans Palmstierna in 1967, these actors managed to reshape the dynamics of the Swedish environmental debate. The conflicts with the established society became more forceful. The alternative movement became visible, and the concept of 'the Green Movement' [literally gröna vågen, the Green Wave, which encompassed a longing for the simple life in the countryside] caught on. Even so, I would argue that commitment to the environment in Sweden - both in the 1970s and today - involved significantly more people than those who were organized. Far from all of them possessed radical left-wing sympathies.

\section{A new history of knowledge}

I reached the above results by applying a history-of-knowledge approach. My ambition was to write a broad social-history narrative about the breakthrough of environmental issues in Sweden. I have done this by studying the circulation of knowledge, both in the public sphere and in the lives of individuals. Throughout the study, I have placed great emphasis on what the historical actors did and on the chronological order in which various events happened. What I have thereby wanted to show is that the social breakthrough of environmental issues was something highly concrete and humandriven: it was not an abstract cultural process that happened by itself. For that reason, too, it looked very different even within the culturally relatively uniform world of Scandinavia. ${ }^{4}$ In order to be

4 Larsson Heidenblad, 'En nordisk blick'. 
able to write this type of history of knowledge, I chose to focus on a relatively short period of time. This limitation made it possible for me to apply a wide-angle perspective to society.

My approach differs in fundamental ways from the previous research which has dealt in various ways with the breakthrough of environmental issues in Sweden. I want to emphasize that this research is rich and of high quality. However, the perspectives employed in it have been both broader and narrower than mine. In chronological terms, the central studies in the field have encompassed many decades. Consequently, the breakthrough years around 1970 were only a small part of a larger historical narrative. Naturally, scholars could not then construct a wide-angle perspective on society. The sole exception is Lars J. Lundgren's study of how acid rain ended up on the political agenda in 1966-1968. ${ }^{5}$ That work, however, illustrates the second difference, which is that the previous historical narrative was narrower than mine in terms of its themes. Interest was focused on specific subjects (acid rain, criticism of growth, nuclear power), organizations (the Centre Party's Youth League, the Swedish Society for Nature Conservation, the Social Democrats), types of media (educational programmes, television journalism), and actors (Georg Borgström). In addition, there are studies of discourses and imageries in which chronology and actors did not play central parts. ${ }^{6}$ In relation to this research, my own study is a hybrid form of empirical research and scholarly synthesis. I believe that my research both deepens and connects the existing knowledge.

5 Lundgren, Acid Rain on the Agenda; Halldén, Demokratin utmanas.

6 Thelander and Lundgren, Nedräkning pågår; Jamison, Eyerman, and Cramer, The Making of the New Environmental Consciousness; Bennulf, Miljöopinionen i Sverige; Johan Hedrén, Miljöpolitikens natur (Linköping: Linköping University, 1994); Anshelm, Socialdemokraterna och miljöfrågan; Djerf Pierre, Gröna nyheter; Holmberg, Längtan till landet; Linnér, The World Household; Stahre, Den alternativa staden; Anshelm, Mellan frälsning och domedag; Eva Friman, No Limits: The 20th Century Discourse of Economic Growth (Umeå: Department of Historical Studies, Umeå University, 2002); Anshelm, Det vilda, det vackra och det ekologiskt hällbara; Linnér, Att lära för överlevnad; Erland Mårald, Svenska miljöbrott och miljöskandaler 1960-2000 (Hedemora: Gidlunds, 2007); Ekberg, Mellan flykt och förändring; Johansson, När man skär $i$ nuet faller framtiden ut; Jenny Andersson and Erik Westholm, Slaget om framtiden: Forskningens roll $i$ konflikten mellan tillväxt och miljö (Stockholm: Santérus, 2019); Mårald and Nordlund, 'Modern Nature for a Modern Nature'. 
My characterization of the Swedish research field also holds true at the international level. There, too, the breakthrough of environmental issues tends to be studied from a longer time perspective. The focus is usually on the emergence of the environmental movements, scientific warning voices, lines of development in the history of ideas, and the level of global politics. ${ }^{7}$ Attempts to write broader narratives of social history are rare, but they do occur. They include Michael Bess's study of French conditions and Frank Uekötter's examination of German ones. ${ }^{8}$ The study that has the most in common with my own is Adam Rome's survey of the US Earth Day celebration on 22 April 1970. An estimated 20 million people took part in the event, and the media coverage was enormous. Around 1,500 colleges and 10,000 schools organized lectures, debates, and demonstrations. The event can be seen as a manifestation of the fact that a social breakthrough of knowledge had occurred in the United States. Earth Day channelled the growing commitment to the environment in a way that was unparalleled in the rest of the world at that time. ${ }^{9}$ For example, the European Year of Nature Conservation in 1970 had nowhere near the same popular support and impact.

In environmental history research, the eventful years around 1970 have been characterized as 'the ecological turn' ${ }^{10}$ But few historians without the environmental prefix speak of that period in those terms. As Adam Rome and Frank Uekötter have pointed out, the emergence and development of modern environmental awareness is poorly integrated into the general historical narrative about the postwar period. ${ }^{11}$ Broader narratives of social history often pass by the phenomenon itself and the relevant processes in silence. I believe that a history-of-knowledge approach which focuses on social circulation is a proactive way of trying to change this state

7 McCormick, Reclaiming Paradise; Guha, Environmentalism; Egan, Barry Commoner and the Science of Survival; Robertson, The Malthusian Moment; Hamblin, Arming Mother Nature; Rome, The Genius of Earth Day; Radkau, The Age of Ecology; Höhler, Spaceship Earth in the Environmental Age; Selcer, The Postwar Origins; Warde, Robin, and Sörlin, The Environment.

8 Bess, The Light-green Society; Uekötter, The Greenest Nation?

9 Rome, The Genius of Earth Day.

10 Engels, 'Modern Environmentalism'; Nehring, 'Genealogies of the Ecological Moment'.

11 Adam Rome, “"Give Earth a Chance”'; Frank Uekötter, 'Consigning Environmentalism to History? Remarks on the Place of the Environmental Movement in Modern History', RCC Perspectives 7 (2011); Uekötter, The Greenest Nation?, pp. 4-11. 
of affairs. When environmental historians such as Adam Rome can demonstrate that they are studying very large social processes and not cultural fringe phenomena, they also gain good arguments for why their field's insights and results must be integrated into historiography at large. ${ }^{12}$

However, the ambition to write broad socio-historical narratives entails practical challenges, not least of an empirical nature. It is de facto easier to study elite actors who operated in public than to study the vast majority who did not. It is also easier to study the environmental commitment of organized activists than to access what housewives, school children, and pensioners thought and did. In the course of my research, I have repeatedly struggled with these issues. It has not been obvious how an intervention based on a history-of-knowledge methodology should be transformed into practical research. But through Hans Palmstierna's abundant correspondence I discovered people like Mats Lidström and Sören Gunnarsson, and I found others via Birgitta Odén's posthumous papers and digitally searchable newspaper archives.

Nevertheless, whether I really succeeded in my intention to study the social circulation of knowledge remains debatable. Perhaps an even larger and more varied body of empirical material would be necessary to achieve that aim? Still, I hope that this study has managed to bring out the benefits of actively striving to build up a wide-angle perspective on society. I also hope that future researchers will take over where I have left off and build on my results, for example by studying Folksam's 'front against environmental destruction' campaign, or the activities of the various educational associations, in greater detail.

Carrying out comparative and transnational projects which examine the social circulation of knowledge is at least as important. In broad syntheses, Ramachandra Guha and Joachim Radkau have shown that the breakthrough of environmental issues really was a global phenomenon. ${ }^{13}$ What happened in Stockholm and New York in the 1970s had counterparts in Tokyo and New Delhi. When applying a global viewpoint, however, it is by no means easy to spot the individuals who made things happen in various contexts. Even very influential actors, such as Hans Palmstierna in the Swedish context, tend to become invisible. Eleven-year-old Mats Lidström

12 Larsson Heidenblad, 'Mapping a New History of the Ecological Turn', pp. 266, 283-284.

13 Guha, Environmentalism; Radkau, The Age of Ecology. 
would scarcely be accommodated at all. But if environmental historians are serious about wanting to integrate the field within a broader historical narrative, I believe they need to use scales that lend visibility to more of the many individuals who became aware of the environmental issues. Historians also need to make concrete comparisons in order to demonstrate distinctions between the various societies.

Another hope of mine is that my own book will be able to inspire history-of-knowledge studies of other social phenomena and time periods. I am personally convinced that actor-orientated studies of the social circulation of knowledge are a fruitful way of conducting historical research. I believe there is a growing need within historical research to go beyond individual case studies and try to attain a more comprehensive grasp of key social phenomena and processes of change. I harbour no illusions that it is possible - or even desirable - to write some kind of total history of society. But within a thriving historical research field, attempts should be made to write broader social narratives, and I hope that the history of knowledge will act as an impetus for this kind of endeavour.

\section{A historian's thoughts about the present and the future}

More than half a century has passed since environmental issues made their major breakthrough in Sweden. For a historian, that is a fairly short period of time; and it is a miniscule amount of time for a climate scientist or a palaeontologist. But fifty years is a long time in a person's life. Mats Lidström's youth and most of his working life have passed. The members of Nature and Youth Sweden who demonstrated at Sergels Torg in Stockholm in 1969 are now retired. Hans Palmstierna died in a drowning accident in 1975. Birgitta Odén died in 2016 after a long and active life of scholarship. Barbro Soller passed away in January 2020.

Even so, the breakthrough of environmental issues remains a historical process that many people remember. For a few more decades, the events will continue to be contemporary history. But for the majority of people now living, including myself, the breakthrough of environmental issues in the years around 1970 is only history. It is something that happened before I was born. My knowledge of it can never be anything other than indirect. But I would still maintain that it is a form of living history. What happened then is affecting us now. The knowledge which circulated in Swedish society at that time is very similar to that circulating here today 
Table 1 Similarities and differences between the ecological turn and the climate debate of our own time

\section{Then as now}

- A global perspective was applied to an interconnected set of problems.

- Hopes were placed in a circular economy.

- Researchers stressed the need for autonomy and a long-term approach.

- People sometimes expressed a sense of powerlessness about the problems.

- The problems were described as 'anthropogenic' and humans as a geological force (this was being done as early as the 1950s, that is, half a century before the concept of 'anthropocene' was coined).

- There were warnings to the effect that a blind faith in economic growth undermines the very basis of our existence.

- People stressed the urgency of steering developments in new directions.

- Some voices argued that technological solutions are not enough, and that social solutions are needed as well.

- Some people implied that democracy might have to be sacrificed in order to fix the problems.

- Campaigners believed that it was necessary to go through young people in order to reach the rest of the population.

- People said we had all the knowledge we needed - the only thing required was the will to act.

- Some voices urged that Sweden should deliberately become a global role model.

- People wondered whether we would be able to look our children and grandchildren in the eye.

\section{Then unlike now}

- At least during the breakthrough phase of 1967-1968, environmental issues were of a non-ideological nature.

- The environmental crisis was a new global survival problem. There was no fifty-year history of scientific warnings, political initiatives, and information campaigns.

- There was no organized environmental movement, and there were no green political parties.

- There was a strong trust in politicians' power and collective solutions.

(see Table 1). I am convinced that the growth and development of environmental awareness is a key part of the history of the postwar period.

However, in the half century that has passed since environmental issues made their major breakthrough, both the relevant set of problems and the knowledge about those problems have assumed 
different forms. Today we talk of a climate crisis rather than an environmental crisis. Of all the undesirable side effects of modern industrial society, rising temperatures are what has caused the greatest anxiety to the largest number of people in the last fifteen years. The really big problem is perhaps not that the natural resources are drying up, but the fact that they are not. Humanity might have been better served by smaller coal and oil reserves.

The 2020s began with fires in Australia and melting ice in the Arctic. Since then, the corona pandemic has overshadowed almost everything else. Many of today's children and young people therefore ask themselves the same question as Mats Lidström did in the summer of 1971: 'How is our little Tellus really doing?' The big difference is that today global mobilization is occurring at the grassroots level. By today's standards, Nature and Youth Sweden's demonstration at Sergels Torg in 1969 was small-scale. Even Earth Day 1970 pales in comparison to today's school strikes and climate marches. There was no Greta Thunberg in the late 1960s or early 1970s.

Despite these differences, as a historian I can still be surprised at how absent the medium-term perspectives of recent history are in today's environmental and climate debate. To me they are so obviously relevant. Those of us living today are not the first people to try to change society in a more sustainable direction. The Swedish government's visions of a fossil-free Sweden in 2045 are not radically different from the 1970s visions of the circular low-energy society. What would happen if an equal effort were to be invested in looking back, trying to learn from the past, as is currently being invested in simulating and forecasting the future? Please do not get me wrong. I do not believe that history has all the answers to the challenges of today and tomorrow. But nor do I think it is of no importance.

I also believe that our varying historical experiences matter more than the political debate suggests. Scientific warning voices were audible throughout the entire postwar period. Knowledge about the future has circulated in the mass media, in parliamentary bodies, and in classrooms. Many people around the world have worried about nuclear war, overpopulation, depleted natural resources, environmental destruction, nuclear power, ozone holes, and climate change. But those same people have also experienced that the future did arrive, and - so far - the great collapse of civilization as we know it has not. How do these historical experiences affect us? Do they keep us awake or lull us to sleep? What do we really believe about the future? And how do these things differ between generations and social groups? 
Additional dimensions exist in the political debate. As far as Sweden is concerned, the period following my investigation came to be characterized by the existence or non-existence of nuclear power. This issue very much shook up the political landscape. In 1980 a referendum was held in Sweden. It decided that nuclear power would gradually be phased out. When I was a child in the 1990s, I learned that nuclear power plants would be shut down by 2010. This did not happen. I believe that experiences of that kind matter, too. They demonstrate the difficulties of deciding what is going to happen in thirty years' time. Within such a long time span, a society and the world around it can and will change fundamentally. It may be worthwhile to remind ourselves of that as we look ahead to 2045.

But history also gives us examples of how major and long-term changes can in fact be implemented. Environmentally hazardous substances such as DDT and CFCs have been banned and phased out. Mercury levels in Swedish lake fish have been declining for a long time. Decisions that were made in the years around 1970 have only had their full impact in our own day. These examples hint at a possible historical lesson. When the problems are concrete and delimited, the possibilities of doing something about them are good, even though implementation may take decades.

However, the really big and difficult questions are of a different nature. Fossil fuels permeate our lives and societies; DDT, CFCs, and mercury did not. Legislation and new technology may not be able to deal with all the undesirable side effects of modern industrial society. Nor is it always easy to rally round knowledge where the big and complex issues are concerned. The relative consensus that may exist during a social breakthrough of knowledge is not necessarily followed by vigorous political action. Conflicts may arise between various legitimate interests and visions.

This is also where one of the biggest differences emerges between the ecological turn and our own time. When knowledge of a global environmental crisis made its major social breakthrough in Sweden, environmental issues were not perceived in ideological terms. Representatives of various political parties and social stakeholders regarded them as scientific and technological issues which could be dealt with along rational lines. A historical window was opened which enabled an actor such as Hans Palmstierna to act as a unifying force for a time. But by the early 1970s, the dynamics had changed fundamentally. The ideological colour of the environmental issues was still not unambiguous; but there was no doubt that they were 
highly explosive ideologically and could cause deep and open conflicts. The Social Democratic establishment, the research community, industry and commerce, the centre-right parties, and the new environmental movements were all drawn into what was sometimes a rather messy struggle over what the concept of the environment should include and what should be done about the concomitant problems. Still, one of the few things that have been possible to agree on is the need for more research and more reliable knowledge.

Personally, however, I sometimes wonder if the environmental and climate debate is and has been excessively focused on issues to do with knowledge. It seems to me that large parts of the political debate are constructed around a naive belief that those who know what is right will do what is right. But what tells us that this is so? Experience? Science? And how do we know when something is 'right'? Perhaps the central place accorded to knowledge is a legacy from the time when environmental issues made their great global breakthrough. In many ways, the late 1960s were a culmination of the postwar belief in science and rational social planning. ${ }^{14}$ Since then, that trust has been replaced by scepticism in many quarters.

But what if knowledge is unable to lead to a sustainable future? In a time of polarization and mistrust, should we turn our backs on science and its representatives? No, I am not saying that. What I do believe, however, is that fundamental questions about how we should live our lives - as individuals, groups, societies, and the human race - cannot be reduced to questions about science. The discussions must also be about values, principles, and historical experiences. For this reason, contemporary historical research is important to the political debate. Like all historical research, it enables us to expand our own experiential space and gain insights into what has shaped those of others. We need more of this, not less.

14 Francis Sejersted, Socialdemokratins tidsålder: Sverige och Norge under 1900-talet (Nora: Nya Doxa, 2005); Per Lundin, Niklas Stenlås, and Johan Grubbe (eds), Science for Welfare and Warfare: Technology and State Initiative in Cold War Sweden (Sagamore Beach, MA: Science History Publications, 2010); Åsa Lundqvist and Klaus Petersen (eds), In Experts We Trust: Knowledge, Politics and Bureaucracy in Nordic Welfare States (Odense: University Press of Southern Denmark, 2010); Östling, Olsen and Larsson Heidenblad (eds), Histories of Knowledge in Postwar Scandinavia. 